\title{
Human adult dental pulp CD117/c-kit-positive networks of stromal cells
}

\author{
M.C. Rusu1,2*, C. Loreto3* , A. Sava4*, V.M. Mănoiu5*, A.C. Didilescu6* \\ 'Division of Anatomy, Faculty of Dental Medicine, "Carol Davila" University of Medicine and Pharmacy, \\ Bucharest, Romania \\ ${ }^{2}$ MEDCENTER - Centre of Excellence in Laboratory Medicine and Pathology, Bucharest, Romania \\ ${ }^{3}$ Anatomy Section, Department of Biomedical Sciences, University of Catania, Catania, Italy \\ ${ }^{4}$ Department of Anatomy, "Gr.T.Popa" University of Medicine and Pharmacy, laşi, Romania \\ ${ }^{5}$ Faculty of Geography, University of Bucharest, Romania \\ ${ }^{6}$ Division of Embryology, Faculty of Dental Medicine, "Carol Davila" University of Medicine and Pharmacy, \\ Bucharest, Romania
}

[Received 24 July 2013; Accepted 13 September 2013]

\begin{abstract}
Dental pulp tissue was collected from 6 healthy adult patients, prior to prosthetic treatments, in order to evaluate the in situ phenotype of dental pulp stromal cells and compare with that of dental pulp stem cells. A CD34-/CD44+/CD105-/ CD117+/CD146-/nestin- phenotype of stromal cells in the dental pulp core was found. Cells with a similar phenotype, but CD44-, were found in the cell rich zone. Dental pulp stromal networks (DPSNs) were found CD117+/CD44+ in the pulp core, but CD117+/CD44- in the cell rich zone. The c-kit-positive DPSNs were contacting pulp nerves and were, in this regard only, comparable to interstitial Cajal cells. Stromal signalling in dental pulp needs further evaluation, in normal tissue as well as a possible cause of persisting pain after endodontic treatments (Folia Morphol 2014; 73, 1: 68-72)
\end{abstract}

Key words: dental pulp stem cells (DPSC), cell rich zone, CD44, stem cells, interstitial Cajal cells-like, stem cells of human exfoliated deciduous teeth

\section{INTRODUCTION}

Dental pulp is a complex microenvironment where mesenchymal stem cells and progenitor cells cohabit [18], usually in perivascular stem cell niches $[7,17,26]$.

It is a great research interest on the dental pulp stem cells, which is justified by their possible use in tissue engineering $[6,12,15]$. Banking dental pulp stem cells (DPSCs) is a good alternative to harvesting stem cells from other tissues [1]. There are defined 3 main types of stem cells in dental pulp: (1) DPSCs; (2) stem cells of the apical papilla; (3) stem cells of human exfoliated deciduous teeth [9, 13, 19, 20, 27].
The immune phenotype of DPSCs was described mostly as it resulted from in vitro experiments. Moreover, phenotypic changes during passages and after adding various markers to medium, are known to occur [23]. However, in vitro experiments offer great information on stem cells, but poor knowledge is added regarding the in situ characterisation of human adult DPSCs.

It was hypothesized that the in situ immune phenotype of stromal cells in human adult healthy dental pulp may be similar to that of DPSCs, but different from the phenotype of cultured DPSCs. Thus it was aimed at studying on ex vivo human dental pulp the immune phenotype of these cells.

Address for correspondence: M.C. Rusu, MD, PhD, Dr hab., "Carol Davila" University of Medicine and Pharmacy, 8 Bd.Eroilor Sanitari, RO-050474, Bucharest, Romania, tel: +40722363705, fax: +40213212284, e-mail: anatomon@gmail.com

*All authors have equally contributed to this study. 


\section{MATERIALS AND METHODS}

Human adult bioptic material (whole dental pulp) was collected from ten healthy single-rooted teeth (maxillary incisors) of 6 adult patients ( 4 females and 2 males; mean age $33.5 \pm 3.2$ years, range $29-37$ ), prior to prosthetic treatments.

Informed consent for use of the bioptic material with research purposes was obtained from the patients. The Ethics Committee of the host institution approved the study.

Before dental pulp extraction, the tooth crown was covered with a $0.3 \%$ chlorhexidine gel for 2 min. Dental pulp was obtained by means of a Gracey curette. The collected samples were fixed for $24 \mathrm{~h}$ in buffered formalin (8\%) and were processed with an automatic histoprocessor (Diapath, Martinengo, BG, Italy) with paraffin embedding. In order to identify specific zones located in the dental pulp, longitudinal cuts were performed. Sections were cut manually at $3 \mu \mathrm{m}$, and were mounted on SuperFrost ${ }^{\circledR}$ electrostatic slides for immunohistochemistry (Thermo Scientific, Menzel-Gläser, Braunschweig, Germany). Histological evaluations used $3 \mu \mathrm{m}$ thick sections stained with haematoxylin and eosin.

The following primary antibodies were used: (1) CD117 (clone T595, Novocastra-Leica NCL-L-CD117, Leica Biosystems Newcastle Ltd, Newcastle Upon Tyne, U.K., 1:20); (2) CD44 (clone DF1485, Novocastra-Leica NCL-CD44-2, Leica Biosystems Newcastle Ltd, Newcastle Upon Tyne, U.K., 1:40); (3) CD34 (clone QBEnd 10, Dako, Glostrup Denmark, 1:50); (4) CD 105 (polyclonal, Thermo Scientific, Pierce Biotechnology, Rockford, USA, 1:50); (5) CD146 (clone N1238, Novocastra-Leica, Leica Biosystems Newcastle Ltd, Newcastle Upon Tyne, U.K., 1:50); (6) nestin (clone 10c2, Santa Cruz Biotechnology, Santa Cruz, CA, USA, 1:500).

Sections were deparaffinised, rehydrated and rinsed in phosphate-buffered solution (PBS) at $\mathrm{pH}$ 7.4. Retrieval by cooking in specific buffer was completed: $0.01 \mathrm{M}$ citrate retrieval solution $(\mathrm{pH} 6.0$, 20 min, for CD117, CD44, CD146, CD105 and nestin) or EDTA ( $\mathrm{pH}$ 9.0, $20 \mathrm{~min}$, for CD34). Appropriate endogenous blocking peroxidase was completed before immune labelling ( $0.1 \%$ BSA in PBS). Sections incubated with non-immune serum served as negative controls. Sections were counterstained with haematoxylin.

The microscopic slides were analysed and micrographs were taken and scaled using a Zeiss working station which is described elsewhere [25].

\section{RESULTS}

The general histological appearance of dental pulp was accurately identified on longitudinal sections of dental pulp. The core of the dental pulp largely contained nerves and microvessels stromal-embedded. At the periphery of the pulp the cell rich zone was identified beneath the cell free zone of Weil. The odontoblasts' layer was discontinuous.

Endothelial cells of the pulp microvessels had a CD34+/CD44+/CD105+/CD117(c-kit)-/CD146+/nestin- phenotype (Fig. 1). CD44 antibodies labelled also Schwann cells in pulp nerves. Stromal networks CD44+/CD117(c-kit)+, but negative to all other antibodies, were found in the pulp core (Figs. 1, 2). CD117/c-kit antibodies, but not CD44 antibodies, also labelled cells in the cell rich zone (Fig. 2).

The CD117/c-kit-positive stromal cells of the dental pulp core appeared either oval, or polygonal, and were sending off thin immune positive processes which were building a rich stromal network. These stromal cells and network were closely related to or were directly contacting nerves and pulp microvessels (Fig. 2).

\section{DISCUSSION}

It has been demonstrated that stem cells can be obtained from dental pulps of subjects aged above 30 years, using specific antibodies for stromal stem cells [16]. It is also known that the cell rich zone of the dental pulp contains DPSCs [3, 6, 29], which are able of producing dentin-like tissue and/or bone $[6,29]$. These cells originate from the neural crest and are multipotent [29].

In the present study the stem cell phenotype couldn't be demonstrated, as reflected by the CD34-/ CD105-/CD146- phenotype of stromal cells in the pulp core and in the cell rich zone. The CD117/c-kit-positive phenotype was observed both in the pulp core and in the cell rich zone. On the other hand, a CD44-positive phenotype was found only in the pulp core, but not in the cell rich zone. Recently, it has been demonstrated that CD44 is expressed in odontogenic cells with active mineral deposition during tooth development. In case of suppression of CD44 expression in dental pulp cells, their mineralization activities were substantially decreased in both in vitro and in vivo assays [5]. CD117(c-kit)+/CD44+ stromal cells in the adult pulp core could be viewed as undifferentiated perivascular and perineural cells. The CD117(c-kit)+/CD44- phenotype of cells found in the cell rich zone is suggestive for a stemness 


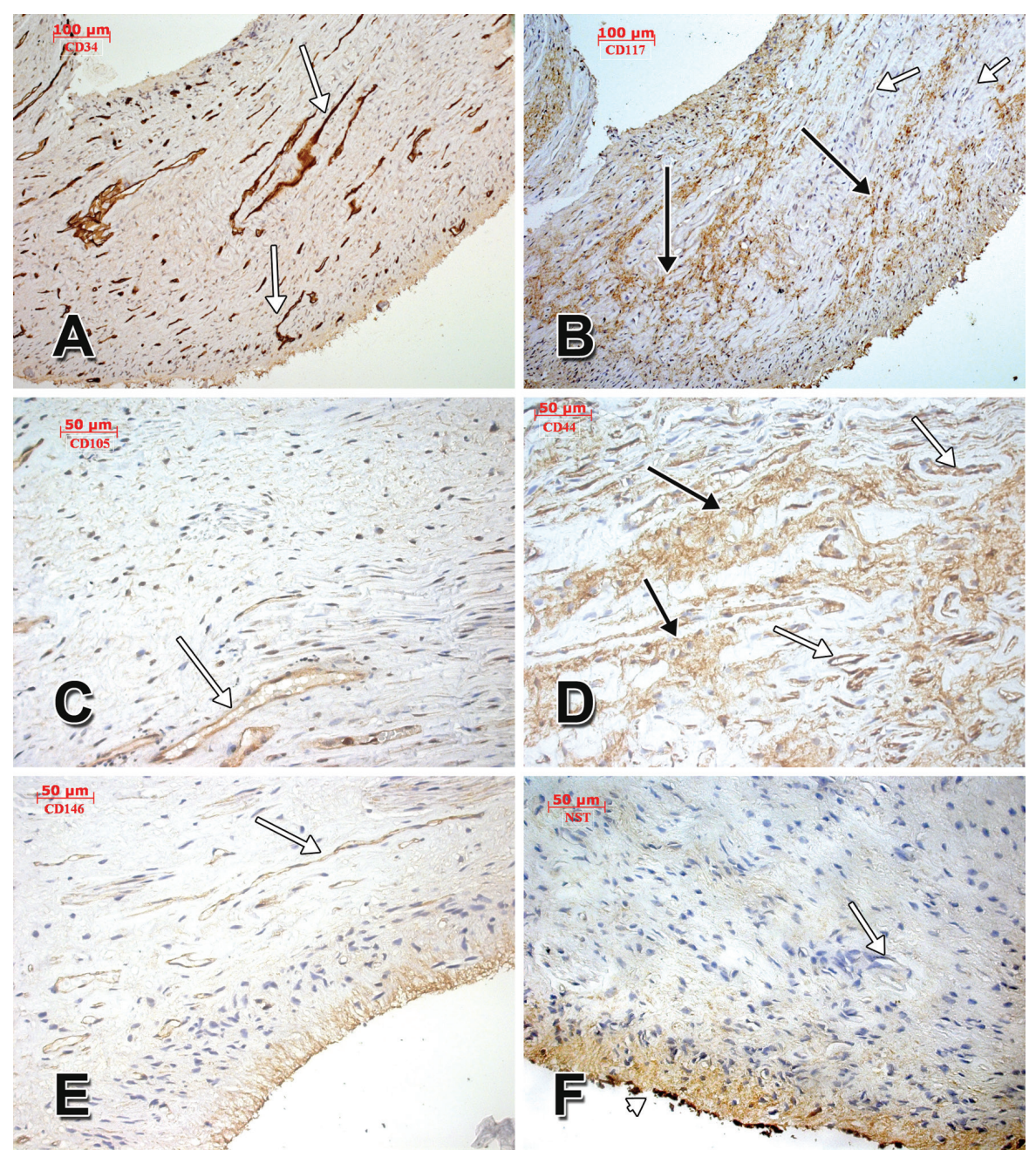

Figure 1. Human adult dental pulp, immune labelling with antibodies against CD34 (A), CD117/c-kit (B), CD105 (C), CD44 (D), CD146 (E), nestin (F). Microvascular endothelia (white arrows) have a phenotype CD34+/CD105+/CD44+/CD146+/CD117-/nestin-. Stromal networks CD117/c-kit+/CD44+ are identified (black arrows) in the pulp core. Nestin + odontoblasts are indicated (white arrowhead).

stage. From this layer, undifferentiated cells migrate to various zones where they can differentiate under different conditions and make new differentiated cells and tissues [6]. The fact that cells committed to odontoblastic differentiation could not be found in this layer, may be due to the integrity of dental pulp and teeth. Under these conditions, lack of stimuli slows down markedly odontoblasts' formation. Further to this discussion, the analysis goes beyond the stem cell or progenitor phenotype. The stromal cells presented here participate in consistent stromal networks (DPSNs) of the dental pulp, and contact nerves. These DPSNs were CD117(c-kit)+/CD44+ in the pulp core, but they were CD117(c-kit)+/CD44- in the cell rich zone. These immune phenotypes determine us to bring in the discussion the interstitial cells of Cajal
(ICCs) which are slow wave-generating cells or mediate neurotransmission [4]. ICCs are not unique to the gut and are present in other rhythmically active structures [14]. In the myenteric plexus c-kit-positive multipolar ICCs form dense networks which envelop ganglia and nerves [4]. These cells are well known for the CD117/c-kit expression [25]. It was also shown that ICCs can also express CD44 [30]. It is not intended to speculate here that pulp stem or progenitor cells are ICC-like cells, as those described in cardiac tissues $[8,10,11,22,28]$ and renamed later to telocytes $[22$, 24]. But it is tempting to speculate similarities between ICCs networks and DPSNs and thus to raise the question on the functional role of pulp stromal cells in stromal signalling and neurotransmission within the human dental pulp. 


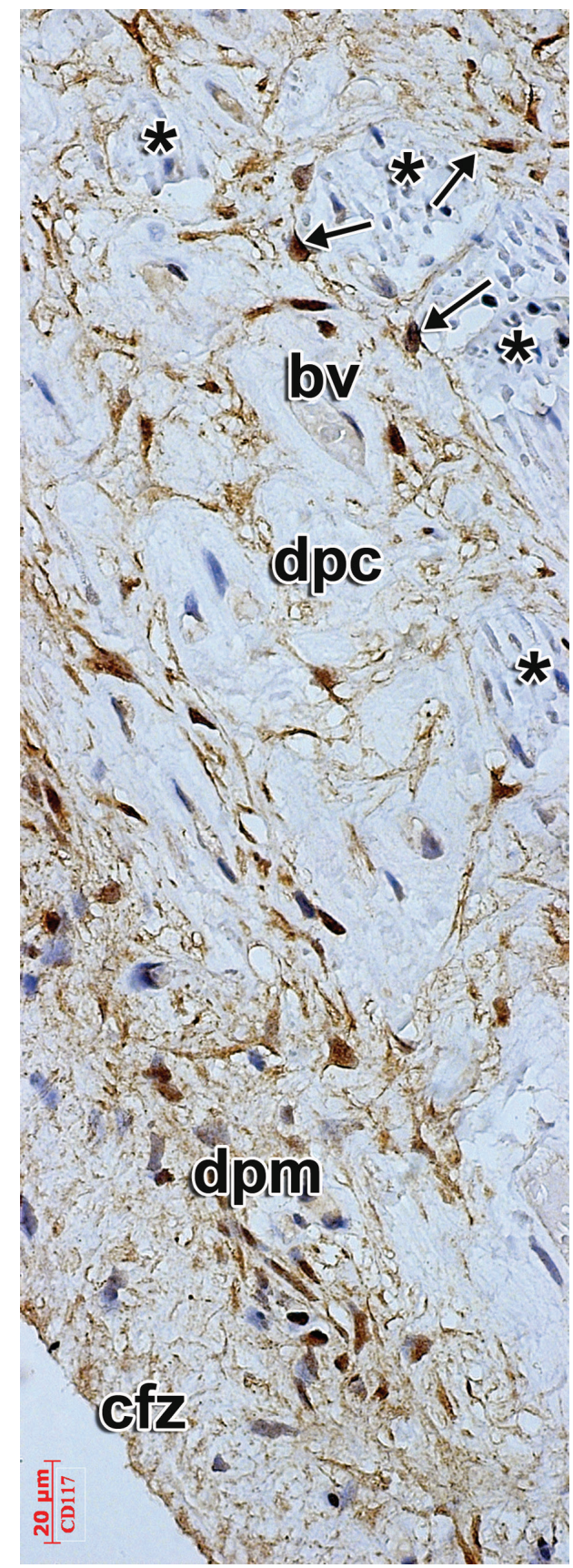

Figure 2. Immune labelling of human adult dental pulp with CD117/c-kit antibodies. Stromal networks built-up by immune positive cells occupy the dental pulp core (dpc) and extend within the dental pulp mantle (dpm, cell rich zone), beneath de cell free zone of Weil (cfz). These networks are closely related to, or contact (arrows) pulp nerves $\left({ }^{*}\right.$ ) and/or pulp microvessels (bv).

Limitations of this study include lack of all stem cell markers previously proposed for DPSC characterisation. However, the panel used here may be enough to reach the conclusion that the phenotype of stromal cells in healthy human adult pulp is distinct from that of DPSCs'. Instead, they present similarities with ICCs, building stromal networks. A role of DPSNs should be further investigated in the normal function of dental pulp and in the aetiology of the persistent pain after endodontic procedures, which occurs in $>5 \%$ of patients $[2,21]$, especially when accessory root canals are overlooked or endodontic treatments are defectuous.

\section{CONCLUSIONS}

The in situ immune phenotype of stromal cells in human adult healthy dental pulp presented similarities to that of ICCs, being different from DPSCs' one. Therefore, these cells might be involved in signalling processes within the dental pulp.

\section{ACKNOWLEDGEMENTS}

All authors have equally contributed to this study.

\section{REFERENCES}

1. Arora V, Arora P, Munshi AK (2009) Banking stem cells from human exfoliated deciduous teeth (SHED): saving for the future. J Clin Pediatr Dent, 33: 289-294.

2. Balto $\mathrm{K}$ (2010) How common is tooth pain after root canal treatment? Evid Based Dent, 11: 114.

3. Brar GS, Toor RS (2012) Dental stem cells: dentinogenic, osteogenic, and neurogenic differentiation and its clinical cell based therapies. Indian J Dent Res, 23: 393-397.

4. Chen H, Redelman D, Ro S, Ward SM, Ordog T, Sanders KM (2007) Selective labeling and isolation of functional classes of interstitial cells of Cajal of human and murine small intestine. Am J Physiol Cell Physiol, 292: C497-C507.

5. Chen KL, Huang YY, Lung J, Yeh YY, Yuan K (2013) CD44 is involved in mineralization of dental pulp cells. J Endod, 39: 351-356.

6. d'Aquino R, De Rosa A, Laino G, Caruso F, Guida L, Rullo R, Checchi V, laino L, Tirino V, Papaccio G (2009) Human dental pulp stem cells: from biology to clinical applications. J Exp Zool B Mol Dev Evol, 312B: 408-415.

7. da Silva Meirelles L, Chagastelles PC, Nardi NB (2006) Mesenchymal stem cells reside in virtually all post-natal organs and tissues. J Cell Sci, 119: 2204-2213.

8. Gherghiceanu M, Hinescu ME, Popescu LM (2009) Myocardial interstitial Cajal-like cells (ICLC) in caveolin-1 KO mice. J Cell Mol Med, 13: 202-206.

9. Gronthos S, Mankani M, Brahim J, Robey PG, Shi S (2000) Postnatal human dental pulp stem cells (DPSCs) in vitro and in vivo. Proc Natl Acad Sci USA, 97: 13625-13630.

10. Hinescu ME, Gherghiceanu M, Mandache E, Ciontea SM, Popescu LM (2006) Interstitial Cajal-like cells (ICLC) in atrial myocardium: ultrastructural and immunohistochemical characterization. J Cell Mol Medicine 10:243-57.

11. Hinescu ME, Popescu LM (2005) Interstitial Cajal-like cells (ICLC) in human atrial myocardium. Journal of Cellular and Molecular Med, 9: 972-975. 
12. Huang GT, Sonoyama W, Chen J, Park SH (2006) In vitro characterization of human dental pulp cells: various isolation methods and culturing environments. Cell Tissue Res, 324: 225-236.

13. Huang GT, Sonoyama W, Liu Y, Liu H, Wang S, Shi S (2008) The hidden treasure in apical papilla: the potential role in pulp/dentin regeneration and bioroot engineering. J Endod, 34: 645-651.

14. Huizinga JD, Zarate N, Farrugia G (2009) Physiology, injury, and recovery of interstitial cells of Cajal: basic and clinical science. Gastroenterology, 137: 1548-1556.

15. Kawashima N (2012) Characterisation of dental pulp stem cells: a new horizon for tissue regeneration? Arch Oral Biol, 57: 1439-1458.

16. Laino G, d'Aquino R, Graziano A, Lanza V, Carinci F, Naro F, Pirozzi G, Papaccio G (2005) A new population of human adult dental pulp stem cells: a useful source of living autologous fibrous bone tissue (LAB). J Bone Miner Res, 20: 1394-1402.

17. Lizier NF, Kerkis A, Gomes CM, Hebling J, Oliveira CF, Caplan Al, Kerkis I (2012) Scaling-up of dental pulp stem cells isolated from multiple niches. PLoS One, 7: e39885.

18. Marchionni C, Bonsi L, Alviano F, Lanzoni G, Di Tullio A, Costa R, Montanari M, Tazzari PL, Ricci F, Pasquinelli G, Orrico C, Grossi A, Prati C, Bagnara GP (2009) Angiogenic potential of human dental pulp stromal (stem) cells. Int J Immunopathol Pharmacol, 22: 699-706.

19. Miura M, Gronthos S, Zhao M, Lu B, Fisher LW, Robey PG, Shi S (2003) SHED: stem cells from human exfoliated deciduous teeth. Proc Natl Acad Sci USA, 100: 5807-5812.

20. Nishino Y, Yamada Y, Ebisawa K, Nakamura S, Okabe K, Umemura E, Hara K, Ueda M (2011) Stem cells from human exfoliated deciduous teeth (SHED) enhance wound healing and the possibility of novel cell therapy. Cytotherapy, 13 : 598-605.
21. Nixdorf DR, Moana-Filho EJ, Law AS, McGuire LA, Hodges JS, John MT (2010) Frequency of persistent tooth pain after root canal therapy: a systematic review and meta-analysis. J Endod, 36: 224-230.

22. Popescu LM, Faussone-Pellegrini MS (2010) TELOCYTES: a case of serendipity: the winding way from Interstitial Cells of Cajal (ICC), via Interstitial Cajal-Like Cells (ICLC) to TELOCYTES. J Cell Mol Med, 14: 729-740.

23. Ruparel NB, de Almeida JF, Henry MA, Diogenes A (2013) Characterization of a stem cell of apical papilla cell line: effect of passage on cellular phenotype. J Endod, 39: 357-363.

24. Rusu MC, Nicolescu MI, Jianu AM, Lighezan R, Manoiu VS, Paduraru D (2012) Esophageal telocytes and hybrid morphologies. Cell Biol Int, 36: 1079-1088.

25. Rusu MC, Pop F, Hostiuc S, Curca GC, Streinu-Cercel A (2011) Extrahepatic and intrahepatic human portal interstitial Cajal cells. Anat Rec (Hoboken), 294: 1382-1392.

26. Shi S, Gronthos S (2003) Perivascular niche of postnatal mesenchymal stem cells in human bone marrow and dental pulp. J Bone Miner Res, 18: 696-704.

27. Sonoyama W, Liu Y, Yamaza T, Tuan RS, Wang S, Shi S, Huang GT (2008) Characterization of the apical papilla and its residing stem cells from human immature permanent teeth: a pilot study. J Endod, 34: 166-171.

28. Suciu L, Popescu LM, Regalia T, Ardelean A, Manole CG (2009) Epicardium: interstitial Cajal-like cells (ICLC) highlighted by immunofluorescence. J Cell Mol Med, 13: 771-777.

29. Tirino V, Paino F, De Rosa A, Papaccio G (2012) Identification, isolation, characterization, and banking of humadental pulp stem cells. Methods Mol Biol, 879: 443-463.

30. Yu B, Han J, He YT, Guo S, Li SF, Mei F (2009) Immunohistochemical study of CD44 immunopositive cells in the muscular layers of the gastrointestinal tract in adult guinea pigs and mice. Acta Histochemica, 111: 382-390. 